\title{
Gender Inequality and its Challenge to Women Development in Nigeria: The Religious Approach
}

\author{
Clifford Meesua Sibani \\ http://dx.doi./org/10.4314/ujah.v18i2.25
}

\begin{abstract}
Obviously, discrimination with respect to gender inequality in Nigeria is at the apex in the contemporary era. Gender inequality is a socio-cultural phenomenon that divides people into various categories such as male and female with a very high bias placing one specifically less than the other. Here attention is given to the sorry and pitiable state of women in Nigeria under marginalization and suppression from the men in a bid to continually exercise undue superiority over them. However, this paper addresses the social status of women in Nigeria: how men have contributed to a slow state of development of Nigerian women via paid employment (socio-economic), socio-cultural, socio-religious and sociopolitical. This research looked at the recommendations of the Committee on the Elimination of Discrimination against Women and its relevance to women development. Religious approach to gender inequality as a panacea to enhance the development of women in Nigerian nation was $x$-rayed. This research made used of historical method, books and journal articles were also consulted.
\end{abstract}

\section{Introduction}

Gender inequality in our society today, is among the most prevalent forms of social inequality which exists all over the world, with different effects in different regions. These differences are primarily due to cultural legacies, historical development, 
geographical location and religious norms which pre-dominate the society. Religion plays a vital role in the cultural life of different spaces. It is deeply rooted in peoples' experiences and influences the socio-economic and political direction of the society. The status of women in the society is an outcome of the interpretation of religious text and the cultural and the institutional set-up of religious communities. The role of religion is obviously complex and it varies across time and space. However it is pertinent for societal development that gender equality and the emancipation of women should be considered as important factors for the economic, social and democratic progress of Nigerian women.

This process can be influenced by institutional norms, as well as culture and tradition, which are both determined by religion. As the relationship between religion and society is reciprocal, religious system in Nigeria are expected to advocate for women liberation and freedom. It is apparently, that the status of the study of women in religion also reflects the status of women in the society as a whole, while considering this fact; this study will $\mathrm{x}$-ray the social status of women in Nigeria, feminism and women development, gender inequality in Nigeria under socio impacts and the under development of women. It went further to view the committee on the Elimination of Discrimination Against Women and how religion is remedying the situation.

\section{Establishing Women Social Status in Religious Nigerian Society}

It is clear that gender roles are primarily constructed through religion, culture, lifestyle and upbringing. The status of women within Nigerian religions is of serious concern to so many in Nigeria and beyond. Aitchison (2007) posits "All world religions 
today maintain male social dominance within a social structure" (p.10). On the other hand, women are more inclined to participate in religious life. The role of God, or a creator of a religion, is always taken by a male and the woman is primarily valued as a mother, especially as a mother to a son. Her place is in the household, less so at religious ceremonies or in public positions. The real status of women in religion is more complicated however religions in Nigeria have encouraged certain women who have risen to significant positions. In the history of religions, the voice of women is rarely heard, due to the patriarchal disposition of the societies in which these religions emerged, and which eventually stifled some of the changes in the status of women triggered by new religions. The world religions all agreed on the respect for women and their crucial role in family life, especially with emphasis on women as mothers and wives. They do not, however, advocate emancipation in the sense of total equality with men. According to Holm (1994):

The most severe restriction apply to women during their menstruation and pregnancy, when, for example, they cannot enter the temple or touch the Quran. Male and female roles are therefore much differentiated and also unbalanced in Nigerian religions. The influence of women on the formation of religious norms and traditions is small, even though in certain doctrines, it is clear that women who succeeded in having their normative views accepted, or, men who advocated equal integration of women into religious ceremonies (p. 34).

It needs to be stated that there exists a certain discrepancy between normative conditionality, which refers to what the given religion 
proclaims (equality of men and women before God) and practical conditionality, which involves the role of women in the religious communities and states societies in terms of everyday life. The Nigerian societies have come of age where women are intellectually capable as men. Butler (1990) opines that woman had numerical parity with men in profession, where educational achievements are so important. In Nigeria today, professionsdoctor, lawyers, accountant, teachers, research scientist and others about half are women. Andrew (2013) states the statistical abstract of United States.

Norms regarding gender are closely linked to the life course established by society. Thus Aries (2015) states that the emergence of childhood revealed the ideals about the appropriate forms of play and educations for boys indeed the very concept of boyhood developed at least a century before the concept of girlhood emerged. In the eighteenth century, African more especially in Nigeria and European societies, the male (boyhood) was conceived at a time when male children could play among themselves and receive education in the skills key would need as adult. The politics in our Nigeria society as it relates a gender places a serious discrepancy. Where male are given prominence and priority over the females (girl) in contrast, were treated as miniature women who were expected work alongside their mothers and sisters. Through these childhood experience, girls and boys learned the norms of gender; the society's definition of what is "masculine" and "feminine".

\section{Feminism and Women Development}

Feminism is the movement of women liberation. The development of feminism was led to attention been focused on the subordinate 
position of women in many societies. In the light of the types of feminism, anchor will be on: Radical feminism and Liberal feminism and their views to women development.

\section{Radical Feminism and Women Development}

Radical feminism became the exploitation of women on men. To a radical feminist it is primarily men who have benefited from the subordination of women. According to Valerie (1999) "radical feminist, see women as oppressed group who had to struggle for their own liberation against their oppressed- that is against men" (p. 225). Pamela (2005) opines that radical feminism tends to believe that they have always been exploited and that only revolutionary change can offer the possibility of their liberation. In the view of Sylva (2011), Marxist and social feminism see capitalism rather than patriarchy as being the principal source of women oppression, and capitalist as the main beneficiaries. Thus the Marxist and the socialist feminist relate women's oppression to the production of wealth while radical feminism attributes greater importance to child bearing. It is the exploitation of women in paid employment.

\section{Liberal Feminism and Women Development}

Liberal feminist aim for general change in the political, economic and social system of western societies, the creation of equal opportunities, particular in education and work, is the main aim of the feminist. Natasha (1998) is of the view that they pursue the aim through the introduction of legislation and by attempting to change attitudes. Liberal feminist maintained that the discontent experienced by many middle class women in postwar Western societies were due to their lack of social power and political influence. The solution they advocated was not necessarily paid 
work outside the home; indeed one of their demands was payment for house wives- a kind of citizens' income - along with representations in public institutions, and so on. Natasha maintained that the liberal feminist embrace power, politics and seek to stem out derogatory names given to women that has infringed on their development it is characterized with local, national transformational activism in area of violence against women, women trafficking, body surgery and new threats to women's rights.

\section{Gender Inequality in the Society and Underdevelopment of Women}

Nmah (2003) is of the view that the resultant weakness of gender inequality has deprived women of the strength to rise up and insist on a change in their environment for the sake of their families and children. Women fear the difficulties of living without a male companion in a man's world. The socio-economic, socio-cultural, socio-religious and socio-political aspects of the underdevelopment of women will be discussed with possible remedies to them.

\section{Socio-Economic Underdevelopment of Women in Nigerian Society}

Nicholson (1990) avers that the position of women in Nigerian culture was dependence oriented hence a common address to women as oriaku, the consumer of wealth. This is to say that women do not play a significant role in the production of wealth in the family. They depend on their husbands for their economic welfare that is why a majority of the women still value the wealth given to them by men as against the backdrop of feeding themselves. There are discriminatory inheritance law and discriminatory land ownership schemes. The women economic 
activities are undervalued and under paid in most cases. This has pushed the women to poverty line; poverty as human right violation is not scarcity of resources but in reality scarcity of democracy. Andrew (2013) states that the weekly earnings of professional woman average $\$ 419$, while for male professionals weekly average $\$ 581$ and the gap between women and men's earnings is often greater in less prestigious occupation. Moreover, women are more likely to be found in less prestigious ones. Clearly, men and women are not equals, at least in terms of earnings and prestige or in power. However Tomoko (2005) observed that nearly two-third of women are employed in 12 occupational groups: the five "C's" caring cashiering, catering, cleaning and clerical occupations- plus teaching, health associate professional (including nurses), and functional managers such as financial managers, marketing and sales managers and personnel managers.

However, the more senior position, the lower the proportion of women. Women take a number of disadvantages in paid work: 1) They tend to be paid less than men. 2) They are more likely to be in part-time work. 3) They tend to be concentrated in the lower reaches of the occupation in which they work. 4) They tend to do particular type of jobs usually those with a low status. Nmah (2003) avers that there are discriminatory laws over the land ownership schemes. The woman economic activities are undervalued and under paid in most cases this has pushed the women to poverty line. The important role and contribution of women in the process of development was not recognized and consequently nothing was done to harness the potential of the women folk in the Nigerian quest for economic development. 


\section{Socio-Cultural Underdevelopment of Women in Nigeria}

Whenever a man has a case against his wife, the woman is always guilty because in Africa, "man cannot make mistake," the fine usually imposed on the woman is usually a cock and kola nuts which are used to appease the "man and the ancestors". During the period the accusation is made the man will not eat any food prepared by the women. Another serious cultural factor that shows subjugation of woman is the male child preference. Case abound where mothers are neglected or thrown out of matrimonial home for failure to give birth to male children. Where mothers are neglected or thrown out of matrimonial home for failure to give birth to male children. Umezuruike (1996) holds that any twin mother in Igbo society was conceived as having committed an atrocious act against the earth-goddess, the mother god of the land. She was seen as been guilty of a great sin and that either of the children must be a monster. The twins were killed in some of African culture not Igbos alone in those days while the women undergo special cleansing if not killed. If the woman's life was spared without any cleansing then the land was seen to have been defiled. The land thus abominated would incur the wrath of the ancestral spirit, which would plague the community. However the intervention of religion especially Christianity, has put a great measure of solution to most of these obnoxious cultural practices in Nigeria.

\section{Socio-Religions Underdevelopment of Women in Nigerian Context}

Sibani (2014) opines that it would be pointless to list the various ways in which the church leaders and the officials of the church can challenge injustice and promote peace; for they vary according to endless varieties of concrete situation in which injustice and lack 
of peace arises. The nature of high level of discrimination against women in African society is alarming and calls for religious intervention especially the church. Dorr (1991) stipulated that the crucial steps should be taken to eliminate gender discriminatory language from all public prayers and church reading; also, a determined effort must be made to enable women play equal part in decision making in the church. Church leaders and local churches in various part of the world have already demonstrated what remarkable contribution they can make once they commit themselves to promoting integral human liberation of women especially widows who are marginalized with respect to property ownership (Luke 18:1- 8). Religion especially Christian religion discriminate against women as it relates to certain responsibilities. Apostle Paul gave a clear instruction that women should be silent in the church. This statement makes women voiceless even when they have good contributions to make to human development. Sibani (2013) clearly states:

The rationale for the decision of male church authorities later exclude women from leadership roles remains open to speculations. What is clear at this point is the effect of their choice. Women in Nigeria are relegated to second-class citizenship with Christianity and African traditional religion and as well as Islamic religion, a status that persist in many religions (Christian denominations to this day. (p. 39).

However, Claire (2003) states that within the Christian tradition, both man and woman have been characterized in contradictory ways. Men are supposed to be rational, authoritative and in control yet they are depicted as weak willed when confronted with 
women's feminine charms. Cowell (1994) and Steinfels (1995) holds that the Catholic has stood firm in its opposition to the ordination of women to the priesthood, with the pope saying that the issue is not even open to debate among the faithful. Church authorities argued that the priest act in the name of Jesus and represent him physically; therefore they must be men. They also pointed out that Jesus called twelve men to be his disciples, not twelve women. However, Stienfels (1995) categorically states that "a commission of biblical scholars appointed by the Pope more than two decades ago concluded that there is no scriptural prohibition of the ordination of women". (p. 34). Sibani (2013) posits that women minister still confront sexism in their churches and denominations. They may experience discrimination in access to leadership positions, ministerial assignment and responsibilities, and salary even if they have higher degrees and more seminary training than most male ministers.

This inequality that has characterized most Christian denominations leads one to wonder how church leaders can reconcile this discrimination with their professed concern for social justice. From the Bible these are some passages that promote gender inequality: 1Timothy 2:12 "but I suffer not a woman to teach nor to usurp authority over the man, but to be in silence". 1 Corinthians 11:7-9 "For a man ought not to cover his head since he is the image and glory of God, but woman is the glory of man. For man was not made from woman but woman from man. Neither was man created for woman, but woman for man". 1Corinthians 14:34 "the women should keep silence in the churches for they are not permitted to speak, but should be in submission as the law also says". Colossians 3:18 says "wives, submit to your husbands, as is fitting in the Lord". 1Peter 3:18 "likewise wives be subject to your 
own husband so that even if some do not obey the word they may be won without a word by the conduct of their wives".

\section{Socio-Political Underdevelopment of Women in Nigeria Occasion by Gender Inequality}

Nigerian women have been long excluded from the practice of politics on the ground that they were seen as unable to cope with the political stress in Nigeria political system. Sibani (2013) opine that the situation is gradually changing as women are advocating for equal participatory right in politics and immediate past president of Nigeria-Goodluck Ebele Jonathan gave considerable response to their plight by giving them appointments and allowing them to contesting for political positions and some emerged winners. Obviously, in our contemporary era it is becoming clearer that the discrimination most Nigerians and Africans had against women has contributed to keeping them in the dark all these years from manifesting their talents and leadership qualities.

Haralambos and Holborn (2008) state that man back up sexual harassment with their powers within any organization. They are usually in the position to "hire or fire" women and may take action against them if they do complain. Stanko (1988) believes that men uses sexual harassment to intimidate women who seek to enter areas of traditionally male employment. There is a need to encourage the females in our society to aspire higher in the political kingdom due to their sincerity and honesty. Nmah (2003) posits that women rarely occupy a political seat among the audience in those days. They were onlookers and in most cases were invited to entertain the audience by dancing or contributing free labour to self- help projects. 


\section{Committee on the Elimination of Discrimination Against Women}

This commission was set up on the status of women and established in 1946. Malcolm (1997) holds that the Commission established the Committee on the Eliminations of All Forms of Discrimination Against Women was established under article 22 of the 1979 convention. Their reports annually go to the United Nations general assembly. They make suggestions and general recommendation as part of their reports. However, some of their recommendations are as follows:

Recommendation No.5 called upon States parties to make more use of temporary special measures such as positive action, preferential treatment or quota system to advance women's integration into education, the economy, politics and employment, while general recommendations

No.8 stipulates that state parties should take further measure to ensure to women an equal terms with men and without discrimination, the opportunity to represent their government at the international level. General recommendation No.12 called upon States parties to include in their reports information on measures taken to deal with violence against women, while general recommendation No.14 called for measures to be taken to eradicate the practice of female circumcision and general recommendations No.21 is concerned with equality in marriage and family relations. Cook (1995) states that in recent years the question of women's right has moved further up the international agenda. 


\section{Religious Approach on Gender Inequality in Nigeria and Women Development}

Obviously women are half of the human race and yet the issue of women's equality still lies unaddressed in Nigerian nation. It is ironic that while humans rights instrument proclaim that everyone is equal, the attainment of the fundamental truth is hamper by tradition. The limitation placed on the attainment of women's equality, by judicial and political understanding of the right of freedom of religion is an apt example of this. It recognized in international and regional for a that women's right are often curtailed or violated in the name of religion as stated by Council of Europe Parliamentary Assembly (2005). However, under this heading, considerations will be given to the following topics: Gender equality within religion in Nigeria as a method for women development, Encouraging women education for women development, and Ensuring that religion becomes part of internal consultation.

\section{Gender Equality within Religion in Nigeria as a Method for Women Development}

The struggle for gender equality for men and women within and outside of religion has always been at the front burner of religious agenda. Of course, the above concern has always provoked mixed reactions among religious leaders in Nigeria as resistance to this change increases on daily basis. The philosophy that all are equal before God is simply a lips service. However, in both mainline and liberal branches of protestant Christianity, women are ordained as clergy. Some Christians believes that if some women have greater opportunity to receive theological training, they will have greater influence on how scriptures are interpreted. In Galatians 3:28, Apostle Paul stated, "there is neither male nor female for all are 
one in Jesus Christ". Some male ministers reject taking Holy Communion from female ministers. They see them as unclean. It is high time for churches in Nigeria to start consecrating their female clerics as Bishops and Archbishops and so on. According to McClain (2010) the Organization Women Living Under Muslim Laws agues thus:

It is only when women start assuming the right to define for themselves the parameters of their own identity and stop accepting unconditionally, and without question what is presented as the "correct" religion that they will be able to effectively challenge the corpus of laws and gender construct thrust upon them. (p. 54).

This does not mean that all women must feel the same way or hold same views within a religion. It merely means that each man and woman should be able to choose what they believe in and not prevent others from exercising their own equal religious right in relation to themselves. Not every religious woman will want to be ministers of their faith, or influence the content of their religion, but every woman, like every man should be given the choice to do so.

\section{Encouraging Women Education for Women Development}

It is the duty of the Nigerian State to facilitate religious change in order to satisfy their international and regional legal obligation in ensuring non-discrimination in the operation human rights. Religious education is a key to equality within religion and also key to equality within the society as a whole. Notions of inferiority and inequality are taught and if this takes place, the battle is almost won. Religious education takes place in families, schools, 
communities and within the church itself. Although the State traditionally only has direct influence over education within schools, this is a good starting point. Abdelfattah (2001) state that the United Nations Special Rapporteurs survey and report on religious education recommended that. "religious education should include education on a range of religions and be focused on the aim of tolerance, non-discrimination and respect for human rights" (p. 31). Boyle and Sheen (2015) hold that there are evidence of women being influential in the teaching and preaching of the early churches. These historical facts can prove to be an eye opener in relation to religious current stance on women and their religious ability. Religious leaders and churches should preach teach hold seminars on gender equality and as well give more scholarship to women to enhance their literacy especially in the rural areas. This will promote women development in all aspect of life.

\section{Ensuring that Religion becomes part of Internal Consultation}

It is important that all those who are claiming to represent a religion and the members of that religion should be clearly identified by the Nigerian state and encouraged to join or enter into an internal consultation process with all her members. The Nigerian State should adopt good practice across religion by organizing, funding and publicizing an inter-faith or inter-religious conference on gender equality. This will bring this subject matter on top of religious agenda of the nation for public awareness. The Nigerian state can sponsor, public reports and documentaries on religious/gender equality in Nigeria. It will not be out of place if gender equality bill is passed in the national house of assembly into law and implementation policies carefully mentioned to give women in Nigeria a fair place in the society. Even those women who are supporting women enslavement should be seriously 
punished by the law. Women development can be very realizable if women themselves reject their present enslavement for the better in Nigerian nation.

\section{Conclusion}

The relationship between religion and gender equality can be explained by the assertion that society with higher religiosity accept the authority of religious teachers, who advocate a patriarchal organization of society. It is obvious that those women, who adhere to the dominant religions, might also not be inclined to take part in their society's public life, due to their up-bringing and social tradition surrounding them. Nevertheless many religious institutions are always helpful for women in economic and social distress. Higher levels of religiosity in Nigeria tend to magnify their gender inequality; however, every religious doctrine has slightly different attitude towards the public participation of women. Today, many women in Nigeria are becoming General Overseers and founders of Ministries due to their calling from God and they are doing exploit. The religious status of women in Nigeria has been addressed. It is worthy of note that this research has given adequate measures of approaches in which religion can emancipate women enslavement and promote equality. However, the religious leaders in Nigeria should fund gender research, preach it in their religious organizations float gender sensitivity and ensure that results are achieved.

\section{Clifford Meesua Sibani}

University of Benin, Benin sibaniforus@yahoo.com 


\section{References}

Abdelfattah, A. (2001). Racial discriminations, religious intolerance and education. Ibadan: Bindle press.

Aitchison, C. (2007). Geographies of Muslim identities: Diaspora, gender and belonging. Ashgate: Aldershot.

Andrew, J. (2013). National and world religion statistcs. Lagos: Kingson

Aries, B. (2015). Gender disparity in Nigeria. Enugu: Okonjo and Okotex.

Boyle, A. and Sheen, O. K. (2015). Religious diversity and human rights. New York: Columbia University press.

Butler, J. (1990). Gender trouble: Feminism and the subversion of identity. New York: Routledge.

Claire, M. R. (2003). Women, men and society. New York: "A and B" publishers

Cook, R. (1995). The elimination of sexual apartheid: Prospect for the fourth world. Washington: LLM publishers.

Council of Europe Parliamentary Assembly (2005). Women and religion in Europe. London: Cotton publishers.

Cowell, A. (1994). Pope rules out debate on making women priest. New York Times, 8-9.

Haralambos, M. and Holborn, M. (2008). Sociology themes and perspective. London: Haper Collins.

Holm, J. P. (1994). Discrimination against women. London: Orishpecta.

Malcolm N. S. (1997). International law fourth edition. University of Cambridge: A. GROTIUS

McClain, O. P. (2010). Negotiating gender, free and equal citizenship: The place of associations. New York: ClassBex. 
Natasha, W. (1998). Feminism: Sex discrimination acts equal pay acts 1970. London: Convent press.

Nicholson, L. (1990). Feminism and postmodernism. London: Routledge

Nmah, P. E. (2003). Women's right in Igbo land: A Christian appraisal. Aba: Soul Winners.

Pamela, A, (2005). Criticism of Marxist and socialist feminism. London: Douglass press.

Sibani, C. M. (2013). The politics of gender and power in Nigeria: The Christian analysis. Journal of Theology, Religion and Cultural Studies, 1,(1), 28- 44.

Sibani, C. M. (2014). Fundamentals of religion and culture in African society. Enugu: Frankpana.

Stanko, E. A. (1988). Keeping women in and out of line: Sexual harassment and occupational segregation. Ibadan: Milton

Steinfels, P. (1995). Vatican says the ban on women as priest is infallible doctrine. New York Times, 12-15

Syvia, W. (2011). Liberal feminism. New York: Routledge

Tomoko, M. (2005). The intervention of world religions: How European universalism was preserved in the language of pluralism. Chicago: University of Chicago press.

Umezuruike, G. C. M. (1996). Obstacles to women equality. Aba: Okolike press.

Valerie, B. (1999). Radical feminism in the $21^{\text {st }}$ century. Durham: Duke. 